\title{
Darkness in the Costume of Whiteness: A Glimpse of Black Gaze, White Mask in Heart of Darkness
}

\author{
Samira Sasani ${ }^{1 *}$, Elmira Molaii ${ }^{2}$ \\ ${ }^{1}$ Shiraz University, Department of Foreign Languages \& Linguistics, Iran \\ ${ }^{2}$ M.A Student of English Literature, Shiraz University, Iran \\ *E-mail address: samira.sasani21@yahoo.com, e.molaii@yahoo.com
}

\begin{abstract}
To begin with, Heart of Darkness has always been challenging for every critic who feels the urge to take either pro-colonialist or contra-colonialist positions. However, herein the main focus would be set less upon the binary stances regarding the protagonist and his leanings toward the natives. Based on the indissociability of the psychological-cum-cultural operations, this study lends itself best to an amalgam of Freudian together with Bhabhian theories such as the dreamwork, repetition-compulsion, mimickry and hybridization. That is to say, it deserves attention to see the colonialist ideology through the dissecting lens of psychoanalysis. Besides, Tiffin's subversive counter-discourse would provide a valuable source to this study. The present study aims to explore the underlying motive for Marlow's narration and his interaction with the natives free from a slippery evaluation of the narratives prime facie. Since any consideration of the native-settler relation without taking the mutual impact of one on the other would only reveal a limited angle to the events, Marlow's narration will be less concerned with the Hegelian subject-non-subject dichotomy than the intersection of both, however disguised. Of particular note is that such intersection gives rise to the ensuing ambivalence at the heart of the text, Marlow's account of events, thence the clash of perspectives, whether fictional or critical, can be discerned. Eventually, this hybrid ambivalence casts the text into a hybrid existence that would account for the narrators' neurosis on the one hand and the contradictory critiques on the other.
\end{abstract}

Keywords: Heart of Darkness; Freud; Bhabha; Dreamwork; Repetition-compulsion; Mimickry; Hybridizing ambivalence; Tiffin

\section{INTRODUCTION}

Thus far, Conrad's novella has given rise to various responses which have turned the text into a battleground for symposium of critical views for more than a century. The critiques run the gamut from one of its first audiences who interpreted it as the binary comparison between the "high-minded British" and "money-grubbing Belgian" to those of the late sixties and early seventies who read it as "attack on Leopold's Congo in particular and the excrescences of imperialist expansion in general" to Chinua Achebe who poised the decanonization of the novel by calling it "offensive and totally deplorable" and labeling its author as "a thoroughgoing racist" (Clendinnen 2). 
Contrary to these rather extreme views if one pays a closer attention to the character of the protagonist, Marlow, who has turned into a wanderer and whose ship is no more his constant home, one probably realizes that such a wandering soul has undergone a nightmarish experience whence he is not recovered quite successfully. Similar to dreams and nightmares, which Freud calls them as the effervescent of the unconscious to be decoded not simply to be understood, but also to be dealt with (Lear 91), Marlow's foggish, baffling experience is contingent upon and flowing from within. In other words, understanding Marlow is the key to the resolution of clashing critical stances and the ambiguity which lies at the heart of the text.

\section{THEORETICAL FRAMEWORK}

The present paper aims to explore the narrative of Heart of Darkness within a dyadic frameworks - psychoanalytic as well as postcolonial. The postcolonial analysis is enmeshed within the psychoanalytic one since the psychological dynamics of the human psyche are intertwined with the cultural operations of his identity. To this end, this study will be based on the theories of Freud such as those related to dreamwork, which is a process by which the conscious thoughts will be restored to the unconscious mind and therefore turn to the latent content, and repetition compulsion, whose source is thanatos whereby it seeks repetition so as to get the neurotic back to the equilibrium and tranquility of nothingness, for final diagnosis of the protagonist.

Moreover issues such as colonial identity and resistance together with repression and Othering, a process by which the colonizer hails the colonized as less than fully human, with the aid of Helen Tiffin's subversive canonical counter-discourse, whose aim is to unmask the colonialist ideology for the postcolonial ends, would be unpacked so as to reshape and rewrite the text anew. Besides, drawn from the theories of Homi Bhabha the dynamics of nativesettler relation -in terms of hybridizing ambivalence related to the way each feels and behaves toward one another, mimickry as two sides of the same coin concerning imitation and resistance and interdependence; that is the mutual impact of one on the other-will be thrown into light.

Of particular note is what brings these mindsets together for a unified analysis of this novella. As for Freud the self is no consistent subject, so is not the relation between the self and the other in Bhabha's theory where he disagrees with former Hegelian master-slave relation where the colonizer and the colonized are concerned. Therefore as the unconscious mind and the dreams it contains illuminate more than a one-dimensional aspect of the mind and the self, in a similar way in Bhabha's phraseology there is more than a binary disparity in the relation of the native and the colonizer. Add to this, Tiffin's views cast light on the kaleidoscopic face of colonialist ideology in its manipulation and description of the natives. Eventually, a merger of these perspectives will shed light on Marlow's ambivalence and the text undecidability likewise.

\section{DISCUSSION}

The essence of the dreaming is the dream-work by which the dream is constructed and every dream is composed of two major determinants: first, the manifest content which transfers the unconscious thoughts to the waking life and we would remember right after the dream. Second is the latent content which accounts for the covert and masked sense of the dream (Lear 102-103). By the same token this narrative would be treated under the twofold significance it holds - the manifest level as well as the latent one. 
In order to get at the latent content of a dream, dream symbols are required to be unlocked. These dream symbols are those of condensation and displacement which occur while dreaming and called primary revision; however what we remember or might not remember properly is the secondary revision of our dream once awake (Tyson 19). It must be noted that what the narrative depicts consciously is the secondary revision, for the most part, related to the manifest account of the experience, while on the other hand a flashback to the primary revision, whence various ideas or objects are concentrated into one object (condensation) and a fairly innocuous object or person substitutes a more threatening one (displacement), would be of the higher concern to this study (Lear 253).

It is this latter sense which quite baffles Marlow and intimidates his true depiction of it as he puts it, "It seems to me I am trying to tell you a dream-making a vain attempt, because no relation of a dream can convey the dream-sensation, that commingling of absurdity, surprise, and bewilderment in a tremor of struggling revolt" (Conrad 32). Stampfl, also terms the ambivalence of the narrative as follows: "it is the speech of someone deluded and yet also deliberately deceiving, who both knows and does not know what he is about" (183).

Since almost every major incidence of the narrative presents itself from the filter of the mentality of Marlow, it is no easy task, with one exception or two, to treat colonial subjects with a clear-cut identity-hence almost all of them appear to him as shadows, their actions if any, are either seen or interpreted by him or his fellow colonizers. So in order to grasp the latent level of his nightmare, it is required to move from the surface toward the kernel; quite contrary to Marlow's strategy for getting at the truth because "to him the meaning of an episode was not inside like a kernel but outside" (Conrad 6).

The analysis of this canonical text follows Helen Tiffin's (post)colonial assertion that reviving or reconstructing the culture of the colonized is no easy task, if possible at all; rather it would be better if one could direct their attention toward the rereading and more significantly "rewriting of the European historical and fictional records" (Tyson 429). Following what Tiffin terms the "subversive [anticolonialist] manoeuvr[e] of [postcolonial] texts" lying in the strategy by which one or more characters, for instance, are analyzed for their "colonialist assumptions" to be uncovered and subverted to postcolonial ends (Tyson 429), a subversive analysis will be undertaken for the unmasking and marginalization of colonialist discourses for the anti-colonialist discourses to come to the central view. The latter discourse is the integral part of the latent level of the dream-like narrative while on the other hand the former is enmeshed within the secondary revision of the narrative.

Whenever Marlow represents colonial subjects, it is without identity as such. He depicts them by and large through stock descriptions and what he recognizes as nonwhite. Certainly, his mentality is affected and shaped by the colonialist ideology therefrom he quite unconsciously defines the colonized by his Eurocentric values. He is white, European and civilized; they are black, African and uncivilized. In other words, he others them; that is to say he, as representative of the culturally privileged, subordinates the unprivileged and treats them as less than fully human so as to assert his power, control and superiority ( Tyson 420-434).

Therefore the colonial subject is described as the other, the inferior, the subaltern whose voice is repressed and whose personality is distorted. All the six frequent images of "darkness," "insanity," "savagery," "paganism," "sexuality" and "disease" are ascribed to the natives and their homeland (Bradley 6-7). At times they are described as cannibals, as this example shows: "more than once she had to wade for a bit, with twenty cannibals splashing around and pushing. We had enlisted some of these chaps on the way for a crew" (Conrad 41); quite often they are called niggers: "the fool-nigger had dropped everything, to throw the shutter open and let off that Martini-Henry" (Conrad 54) and other times are referred to as 
shadows: "nothing but black shadows of disease and starvation, lying confusedly in the greenish gloom" (Conrad 19).

Another instance of stereotypical white description of the black and downsizing them to animals is Marlow's portrayal of his riverboat's boiler as he remarks: "to look at him was as edifying as seeing a dog in a parody of breeches and a feather hat, walking on his hind legs.' Africans cannot be changed. They can only be corrupted, or destroyed" (Clendinnen 4). In a similar vein, the narrative toys with "Manichean" (Nayak 34) binary dichotomy of light and dark by attributing positive senses to the former and evil and scary connotations to the latter. Such dark-white binary is not so much congealed as it proves to be protean and altering.

However, for now, this twosome opposition particularly makes sense as the manipulative idea inherent in the psychology and integral to the cultural practices of colonization. And it is this simple, however clever, idea that guarantees the sovereignty of the colonialist and leads to the subalternity of the colonized; it legitimizes the white say-so to step farther outside their ambit and abuse both natives and their land for exploitative ends. Marlow says he is "something like an emissary of light, something like a lower sort of apostle (Conrad 14) though he admits "[his]head had nothing in it but that wretched steamboat business (Conrad 29). Similarly, one of his fellow friends in response to why he has come there replies “to make money, of course. What do you think?"(Conrad 23).

The native's resistance to colonial control and invasion is not deemed as their right but as an anomaly of savagery which occurs mainly by violence and must be repressed and civilized out of hand. The first example of resistance of the natives over the colonizers is in the squabble which starts over two black hens; though the son of the chief of the village kills the captain of the company, his reaction is less an act of violence than that of tutelage. Another instance is the scene of the attack of Marlow's helmsman and ship which proves to have been stimulated by Kurtz, the white chief of the "Inner Station" (Conrad 29). Even so during much of his journey, Marlow and his crew are afraid of the native's potential attacks even after meeting with Kurtz until he dies.

Once the colonizer's security, particularly financially, is threatened they appear to be more inclined to suppress and sublate the natives by hook or by crook. Besides the previously mentioned stock descriptions and demonization of the colonized, you can add hatred and violent suppression as the next determinative factors of the colonialist ideology, another concomitant of othering or rather one of its repressive means. This hatred and violence can be easily found in the chief agent of the first company's remarks while he admits "when one has got to make correct entries, one comes to hate those savages - hate them to death" (Conrad 22). The Same hostility is to be equally noticed in ivory-hungry Kurtz's true mission as Clendinnen affirms: "this kind of anger is fully explicit in the jagged scrawl Kurtz appends to his shining report to the 'International Society for the Suppression of Savage Customs': 'Exterminate all the brutes!'” (16).

Likewise images of dark violence, hunger, bloody wounds and such-like are depicted frequently and in minute detail that one comes to the bitter fact that not only the sight of, but also the wording of such atrocities take a real brute to bear. Most of the brutal scenes come to Marlow's sight in his on-foot journey through jungle where he faces, in contrast to the company's chief accountant, anything except some fresh air to breathe on. During his walk he confronts "the body of a middle-aged negro, with a bullet-hole in the forehead, upon which [he] absolutely stumbled three miles farther on..." (Conrad 23). And more often than not, he refers to the groans and moans of a native who has been accused of causing the fire for which he was beaten hard and his groaning makes Marlow quite uneasy; conversely this is the judgment the mustached man passes over the native victim: "“what a row the brute makes!"”; 
"'Serve him right. Transgression — punishment— bang! Pitiless, pitiless. That's the only way. This will prevent all conflagrations for the future "' (Conrad 30).

Native women are depicted through Marlow's eyes not much better than men; he depicts Kurtz's so-called mistress as mysterious, wild and dangerous. This is how she looks in Marlow's words:

She carried her head high; her hair was done in the shape of a helmet; she had brass leggings to the knee, brass wire gauntlets to the elbow, a crimson spot on her tawny cheek, innumerable necklaces of glass beads on her neck; bizarre things, charms, gifts of witch-men, that hung about her, glittered and trembled at every step. She must have had the value of several elephant tusks upon her. She was savage and superb, wild-eyed and magnificent; there was something ominous and stately in her deliberate progress. (Conrad 72)

Later, he calls her wilderness itself: "She stood looking at us without a stir and like the wilderness itself, with an air of brooding over an inscrutable purpose" (Conrad 72).

In an opposite vein, at the sight of the portrait of Kurtz's "Intended" (Conrad 85) he says, "she struck me as beautiful-I mean she had a beautiful expression" (Conrad 86). While the native woman is compared to the wilderness in all its dark, sexual and mysterious senses, the white woman is called beautiful. This single phrase suffices for distinguishing the white European woman from the Other. Later, Marlow delineates this silent picture of the native woman: "She looked at us all as if her life had depended upon the unswerving steadiness of her glance. Suddenly she opened her bared arms and threw them up rigid above her head, as though

in an uncontrollable desire to touch the sky..." (Conrad 73).

In so doing, Marlow others the native woman by calling her the voice of wilderness and darkness; however Marlow himself, turns to her voice and talks for her by giving a statuesque depiction which hardly can, if at all, represent the true essence of her humanity. On the other hand, the Intended's conversation with Marlow is enough to grant her so strong a voice to force Marlow to lie about the death of Kurtz as she says, "'His last word - to live with,' she murmured. 'Don't you understand I loved him-I loved him-I loved him!"' (Conrad 92). This is to say, the voice of the white woman champions Kurtz and makes Marlow not to admit the reality of his death which he could have dealt with otherwise if only he could unfetter himself of the pressing voice of the Intended. Thus, he raises the Intended's voice at the expense of lying to his own self. Conversely, the native woman, hence her blackness, is unvoiced by being deprived of her only vehicle for expressing herself.

Finally, the last example of the natives' repression and silencing takes place with the appearance of the Russian boy who has attracted a myriad of responses from critics such as John W. Canario who sees him as "a white aborigine" representative of high primitive and innocent capacity for fellowship and less avarice compared to Kurtz (Peters 96) and Jack Helder who calls him "traditional simpleton" and "sinister" for his defective way of understanding Kurtz in comparison to Marlow (Peters 96). Given the two mouthpieces' critiques one cannot help but to think of a third category which for the most part puts him in relation to the natives. The point herein is that in shaping of Marlow's interpretation of Kurtz, even prior to Kurtz and his Intended, The Russian plays a manipulative role. Without tremor, he reaches this end not just by putting Kurtz on a pedestal by his constant praise of him: "Ah! I'll never, never meet such a man again. You ought to have heard him recite poetry-his own too it was, he told me. Poetry! He rolled his eyes at the recollection of these delights. Oh, he 
enlarged my mind!" (Conrad 75); but through a vehicle which, for the most part, goes unnoticed: ventriloquism of the natives by all means. Once asked by Marlow whether Kurtz got the natives to abide by his commands, as Marlow points out, "he fidget[s] a little" and then replies: "They adored him" (Conrad 66).

Immediately after this conversation, Marlow mentions the changing tone of the Russian's voice and how he could notice he is filled with an amalgam of two opposite forces of both "eagerness" and "reluctance" to talk about Kurtz (Conrad 66). Definitely for this reason the Russian is not to be trusted and speaking in place of the natives worsens his situation. That is why "Marlow finds himself floating in air, forced by Kurtz to "invoke himhimself" as the only standard of moral judgment" (Tabachnick 194). In psychological terms all these examples are the manifest side of the narrative which deals mainly with the colonized, through its characters and narrators, more or less in the same way. It stereotypes all the natives with negative terms and masks the majority of the events with civilizing mission. However, like a dream it hints at the deceptive duality of the colonizers and the forces such as groan and moan of the natives, the changing tone of the Russian's voice and the force of the Intended demand are all symbols of uneasiness to Marlow, though not surfaced to his conscious mind substantially to help him resolve his uncertainty.

By far, the analysis has mainly been concerned with the secondary revision of the dream-like narrative which, in postcolonial words, can be called the colonialist ideology, its psychological and cultural manifestations, and its repressive vehicles, though merely hinted. Now that the colonialist ideology is unmasked whereby everything is in a binary contradiction with what it terms as Other for itself to be defined, idolized and stand out as superior, it is time to step back to the primary level of the dream, decode its symbols of which Marlow has been ignorant and to reveal how the text itself subverts its ideological foundation through the wording of Marlow.

As the narrative unfolds, it becomes evident that, for Marlow, the images of dark and light and their associate senses fluctuate so frequently and contradictorily that the whole concept of dark and light and their common dichotomy become topsy-turvy by the end. At first the darkness flows rather out there in the utter savagery, wilderness that stirs in the forest, in the jungles, in the hearts of wild men, mysteriousness, evil or put another way runs in the natives' physical darkness, their miserable life and their land. On the other side, light accompanies health, whiteness and European civilization. This is to say, up above, multiple images are condensed into a single image whether dark or otherwise.

However, these concepts are mostly related to the manifest orientation of the dream narrative. Since dark and light on secondary level refer to the binary dichotomy of black and white with all the associative senses already discussed as integral to both psychology and ideology of colonialism. As the narrative moves further, it points its direction toward light images, though the projection of inner darkness onto outer elements continues to the end of the journey; there are moments when fog and whiteness are depicted as obfuscating as darkness and even a barrier to the sight of the darkness itself. Yatzeck refers to this quality as "blind whiteness" (Conrad 49) while he says that light is a means of deceit in this novella and it is not to "illuminate darkness", but "in a sense it is the darkness" itself (Bradley 2). Here is an instance of such blind whiteness in Marlow's words: "Well, you may guess I watched the fog for the signs of lifting as a cat watches a mouse; but for anything else our eyes were of no more use to us than if we had been buried miles deep in a heap of cotton-wool" (51).

Also Watts, refers to the "paradoxical" and even subversive "associations" of white and black and their manipulative function (21). Likewise, for Daleski "the white fog obscures sight, which Conrad had argued was his primary artistic goal: "to make you see"" (Peters 38). 
It must be noted that white and dark images in their imperialistic ideological sense for the purpose of Othering and marginalizing the natives are rampant throughout the narrative on the surface. Only in one case this dark-white duality is comingled and this occurs right at the end of the journey into the heart of darkness; the instant that Marlow happens to stand up against Kurtz. At this point the former condensation of civilization and the developed into whiteness and primitivism and the undeveloped into darkness is toppled and mixed to have all the former binary images condensed into a blurred whitish dark and vice versa.

Just as the narrative is divided into two levels of significance, so is Marlow split between ambivalence and resistance. In other words, one is the concomitant of the other; as the text is plagued with insecurity and uncertainty so is Marlow; concurrently Marlow's ambivalence is ensued by the ambiguity of the text. According to Bhabha the relationship between "colonizer" and "colonized" is more complicated, illusive, and delicate than appears prima facie due to the role of "unconscious operations" in determining both "identity" and "agency" in the "colonial context" (Schwarz et al. 457). This accounts for the lack of security of the colonizer and his subsequent "destabilizing ambivalence of his psychic affect and identification" which influences his representation of the colonized (Schwarz et al. 457). Marlow appears, on more than one occasion, to be under such ambivalence in his description of the natives. His depiction of them is instantaneously vacillating between two sentiments: contempt and fellowship.

Thus in some cases Marlow "reserves a special contempt for the African who apes white ways and manners" (Clendinnen 6) since he is produced by the same sense of ambivalence that shapes "colonial subjects which are 'almost the same but not quite' (and later, 'almost the same but not white')" (Selden et al. 227). On other occasions, however, he takes another attitude toward them as when he encounters the young native boy in a miserable situation in his journey through the forest and offers him one of his "good Swede's ship's biscuits"(Conrad 20). In another instance he talks of the labeling of the natives by his white friends scornfully; names such as "'savages,' then 'workers,' 'enemies,' 'criminals,' 'rebels,' according to the needs of the moment: any label that might justify cruelties, including stupid and futile ones" (Clendinnen 6). The other example is the initial fear he holds toward the black men on his ship who are said to be cannibals; however later in the narrative he passes another judgment upon their great capacity for abstinence and humanity despite their hunger:

I looked at them as you would on any human being, with a curiosity of their impulses, motives, capacities, weaknesses, when brought to the test of an inexorable physical necessity. Restraint! What possible restraint? Was it superstition, disgust, patience, fear- or some kind of primitive honor? No fear can stand up to hunger, no patience can wear it out, disgust simply does not exist where hunger is; and as to superstition, beliefs, and what you may call principles, they are less than chaff in a breeze .... It takes a man all his inborn strength to fight hunger properly. It's really easier to face bereavement, dishonor, and the perdition of one's soul - than this kind of prolonged hunger. (Conrad 49)

This depiction of supposed cannibals with high capacity for restraint is what disintegrates "the western values" on the concept of the civilized and uncivilized for Marlow to take sides with the cannibals who prove to be more humane than the white colonizers; hence more civilized (Peters 45). Last but not the least, comes his ambivalence toward his helmsman where his sentiments are not so much of pity than they are of mixed friendship and 
fear; no more a one-way relation but a mutual responsiveness. This hodgepodge of emotions cannot be understood unless the cause of the ambivalence is elucidated, and the complicated dynamics of their relation are demystified. It is worth mentioning that in this case especially, the manifest content including the parts which are mainly mentioned through Marlow's colonizing voice and the latent one which is more inferred than stated directly through his humane voice-- sometimes interacting with, sometimes contesting each other-- synthesize in ambivalence.

For Bhabha "the vulnerability" of the colonizer lies at the very root of his "narcissistic demand" that he should be "addressed directly" and that "the Other" should "authorize the self" by recognizing its superior position through the reiteration of its basic references while he "stills his fractured gaze" (Schwarz et al. 458).

Because this narcissistic mentality gains its legitimacy through the distinction between the self and the Other it will result in a dyadic system of mimickry. "Mimickry" is a "strategy of power as well as resistance" based on "cultural difference" which instigates the colonized imitation of the colonizing demands and requires them to mirror back the image of obedience while at the same time it incites challenge and resistance to the "universal values" of western ideology (Schwarz et al. 459). This relationship between the dominant and the inferior culture is not "antagonistic" as much as it is "agonistic" (Schwarz et al. 461). This is the reason why Marlow fluctuates between agony for the loss of his helmsman on the one hand and horror which makes him get rid of his corpse on the other. The "ambivalence which each [the colonizer or the colonized] feels towards the other contains some measure of desire and both are in some ways mutually in need of each other" (Schwarz et al. 461). Below comes an example of such ambivalence:

I missed my late helmsman awfully, - I missed him even while his body was still lying in the pilot-house. Perhaps you will think it passing strange this regret for a savage who was no more account than a grain of sand in a black Sahara. Well, don't you see, he had done something, he had steered; for months I had him at my back - a help - an instrument. It was a kind of partnership. He steered for me-I had to look after him, I worried about his deficiencies, and thus a subtle bond had been created, of which I only became aware when it was suddenly broken. (Conrad 60)

In a sense, Mimickry, in Bhabha's words, suggests "strategic reversal of the process of domination . . . that turns the gaze of the discriminated back upon the eye of power" (Schwarz et al. 459). Fortunately, in the light of this sense of mimickry Marlow's exasperation under the challenging gaze of the helmsman becomes more evident. Marlow already reveals uneasiness at the sight of wounded man's "black death-mask" that stroke him with "inconceivably somber, brooding, and menacing expression" (Conrad 55). Later, however, by his own account, it becomes evident that the primary reason for his tipping the corpse of the helmsman overboard was not the fear of the cannibals who might have eaten him (Conrad 61) rather it was because "[he] had to make an effort to free [his] eyes from [the helmsman's] gaze and attend to the steering" (Conrad 55).

So far, a good deal of the latent content of the nightmarish narrative or the subtext has been deciphered and it was revealed how the text itself engages in the process of canonical counter-discourse toward the subversion of its colonialist ideology or its dominant text. now it is time to head toward the single climactic moment thenceforth the dark and white images get blurred, the colonialist ideology is shaken and the unitary concept of self and the 
psychological equilibrium of Marlow are disturbed to the point of casting him in a situation where he loses stability and will suffer an in-between existence.

Unlike the "Hegelian master/slave dialectic" or the fixed division of "colonizer/colonized", Bhabha extends the boundaries between the sides of colonial equation, by mentioning a third category which includes "a discrimination between the mother culture and its bastards, the self and its doubles, where the trace of what is disavowed is not repressed but repeated as something different - a mutation, a hybrid" (Rivkin et al. 1174). Therefore, "the displacement from symbol to sign creates a crisis for any concept of authority based on a system of recognition: colonial specularity, doubly inscribed, does not produce a mirror where the self apprehends itself; it is always the split screen of the self and its doubling, the hybrid" (Rivkin et al. 1176). To put it another way, what a subject sees in the screen of the other is no more a unified symbol of inferiority or superiority; instead he would see a blending of his own image and that of the other.

It is this third category which causes an ambivalence which is no more based on a universal symbol than it is grounded upon the sign of difference; and this is what momentarily, though fiercely, occurs to Marlow by the death of his helmsman. However, he tries to flee from it by all means and to get him out of sight to unburden his mind from all the potential pernicious consequences and manages to do so quite successfully till he repeats the same hair-lifting experience in the wilderness with Kurtz, a white colonizer. The eye-to-eye confrontation with Kurtz is the moment of psychological as well as cultural and ideological disintegration of Marlow. Thus, Marlow-Kurtz encounter is no more the meeting of the self and the Other as it truly is the visit of the self with a doubling; a hybrid.

Psychologically, he becomes unsettled as he confronts Kurtz who is divided between two ids: "the European id" and "the irrational id" while his ego fails to mediate between the two (Assad Nassab 33). This is the exact instant that totally neutralizes his former convictions about the self and the Other and the unitary concept of the self in general. He formerly believed that "Africa was once European reality: the barbarians are what we were not so long ago" (Peters 96); that is he projected the irrational side of the human psyche to the Other as well as to the bygone past. However, at this moment he sees that this side of the human's kaleidoscopic self has always been with him and ever will be whether curbed or otherwise.

In order to understand how Marlow is disintegrated culturally, the relation between Kurtz and the deceased helmsman must be noted in the first place psychologically. He compares them together because he thinks the helmsman did not have "restraint" the same as Kurtz (Conrad 60). Nayak also, notes this connection as he puts it, "Marlow's narrative has also asserted Kurtz's renunciation of his Western self and a connection between him and Marlow's deceased African helmsman" (44). Why should Marlow compare his helmsman whom he misses so much with Kurtz who was not "worth the life they lost in getting to him" (Conrad 60)? Kurtz is rather less threatening and of course a milder displacement of the helmsman on the latent level, after all he is got the white mask. This is the time while the last sense of whiteness is uncovered since it is even worse than being the equivalent of darkness; it is a deluding mask for darkness.

The meeting with Kurtz is in fact the confrontation with the native helmsman whose gaze dismantles Marlow's cultural and ideological western beliefs. The power of the gaze is in that it no more appears to Marlow as a European symbol of essentialist universalism than it stares at him as the sign of difference; the two sides of the same coin; the point of contact, something between either and or of both colonial and counter-colonial dynamics. This last gaze is in fact what unsettles and consequently dismantles Marlow's colonialist ideology. It no more reflects a unitary image of universalism; conversely it mirrors back a hybrid image 
on the eye of power; hence the hybridizing image is nothing other than Marlow's reflection of hybrid self in the mirror of the Other.

Since the narrative cannot take any fixed position in relation to what it explains or put another way since none of the narrators, neither Kurtz nor Marlow nor the unnamed narrator of the frame tale takes a certain attitude toward what they experience, see or hear they fall prey to what Freud calls "repetition compulsion" the source of which is due to a force whose aim is repetition (Lear 256). Marlow's ambivalence is his stimulator in narrating his nightmares as Elliot states: "even after Marlow has seen the blackness of Kurtz's soul, he still begins his narrative on the Nellie by talking of the "idea" that "redeems" conquest of the dark places" (165). Quite similarly the frame listener admits the same uneasiness which urges him to become in turn the narrator of Marlow's story. "The others might have been asleep, but I was awake," says the frame narrator. "I listened, I listened on the watch for the sentence, for the word, that would give me the clue to the faint uneasiness inspired by this narrative" (166). Ergo "Marlow's narrator is left looking into the ever-present darkness of his own heart" (Tabachnick 198).

\section{CONCLUSION}

After all, each hearer in this narrative feels an urgent need to "infect" his hearers, hence "each of the chosen hearers in Heart of Darkness is compelled to become in turn a teller" (Elliot 173). Their experience requires them either to die or to go through a repetitive cycle of narration. Kurtz dies while he repeats two words "'The horror! "The horror!'” (Conrad 83) that Marlow comes to interpret as a sign of Kurtz's remarkability (Conrad 84). Obviously, he ignores the evident proof that reveals Kurtz is compelled to tell his story and is fortunate enough to die. Nor does he notice that by lying to the Intended for the sake of Kurtz, he falls victim to repetition. He says that he hates lies because "there is a taint of death, a flavor of mortality in lies,- - which is exactly what I hate" (Conrad 31). How paradoxical that he has to suffer the compulsion to repeat whose force is nothing but the death-drive itself - a repetition which takes him "backward" (Lear 160).

Now the fact that critics have responded to the colonial context of the narrative in a cacophony of contradictory voices makes sense and it is possible to say why critics have mostly regarded the character of Kurtz not as a compelling part of the novel's critique of imperialism but as an example of the novel's complicity with the "imperial imaginary" (Nayak 43). Marlow's attempt to take Kurtz back to the ship has been interpreted as an act of restoring him to civilization (Clendinnen 13) or as a "mission" which accompanies "transformation from wilderness to garden" (Hansson 3); however this attempt is suggestive of Marlow's resistance to the gaze which mirrors back his reality and insistence on the colonialist ideology. It is this resistance that turns him to a neurotic who is compelled to put his nightmarish dream into words - effervescent of manifest and latent significance. Finally, through this resistance and ambivalence, the text as such turns to a hybrid, akin to the narrators, taking an in-between attitude toward both sides of the colonial equation-- colonialist as well as anti-colonialist. Thus one might say Kurtz is neither as much as he is both-the text is shaped by a hybrid inasmuch as its subtext shapes the hybrid. In other words the relation between the hybridity of the narrator and that of the text is mutually constitutive. 


\section{References}

[1] Assad Nassab, S. A Postcolonial and Psychological Approach to Heart of Darkness. MA thesis. Lulea University of Technology. (2006).

[2] Bradley, C. Africa and Africans in Conrad's Heart of Darkness. A Lawrence University Freshman Studies Lecture. Appleton: Lawrence Univ. (24 Jan. 1996).

[3] Clendinnen, I. Preempting Postcolonial Critique: Europeans in the Heart of Darkness. Common Knowledge 13(1) (2007) 1-17.

[4] Conrad, J. Heart of Darkness. Univ. Park: Penn State Electronic Classics. (2000). Received from: http://www.hn.psu.edu/faculty/jmanis/josephconrad.htm

[5] Elliott, D. W. Hearing the Darkness: The Narrative Chain in Conrad's Heart. English Literature in Transition 28(2) (1985) 162-18.

[6] Stampfl, B. Marlow's Rhetoric of (Self-) Deception in Heart of Darkness. MFS Modern Fiction Studies 37(2) (1991) 183-196.

[7] Hansson, K. Entering Heart of Darkness from a Postcolonial Perspective: Teaching Notes. Karlskrona: Psilander Grafiska (1998).

[8] Lear, J. Freud. New York: Routledge (2005).

[9] Morgan, J. Harlequin in Hell: Marlow and the Russian Sailor in Conrad's Heart of Darkness. In Bloom's Modern Critical Interpretations: Joseph Conrad's Heart of Darkness. Harold Bloom (Ed.). New York: Infobase Publishing (2008) 95-103.

[10] Nayak, S. Two Narratives of Modernism in Heart of Darkness. Conradiana 44(1) (2012) 29-49.

[11] Peters, J. G. The Opaque and the Clear: The White Fog Incident in Conrad's Heart of Darkness. In Bloom's Modern Critical Interpretations: Joseph Conrad's Heart of Darkness. Harold Bloom (Ed.). New York: Infobase Publishing (2008) 37-50.

[12] Rivkin, J., and M. Ryan. Literary Theory: An Anthology. Maiden: Blackwell (2004).

[13] Schwarz, H., and S. Ray (Eds.). A Companion to Postcolonial Studies. Malden: Blackwell (2005).

[14] Selden, R., P. Widdowson, and P Brooker. A Reader's Guide to Contemporary Literary Theory. London: Longman (2005).

[15] Tabachnick, S. E. Two Tales of Gothic Adventure: She and Heart of Darkness. EnglishLiterature in Transition 56(2) (2013) 189-200.

[16] Tyson, L. Critical Theory Today. New York: Taylor \& Francis Group (2006).

[17] Watts, C. Heart of Darkness. In Bloom's Modern Critical Interpretations: Joseph Conrad's Heart of Darkness. Harold Bloom (Ed.). New York: Infobase Publishing (2008) 19-36. 